\title{
The Meaning Of Nutmeg And Clove North Maluku In Popular Culture
}

\author{
Jerry Dounald Rahajaan \\ e-mail: jerry.dounald@uniku.ac.id \\ Sigit Setyakusuma \\ e-mail: sigit.setyakusuma@uniku.ac.id \\ Visual Communication Design Department \\ Computer Sciences Faculty- Kuningan University \\ e-mail: jerry.dounald@uniku.ac.id
}

\begin{abstract}
Abstrak
Makna filosofis yang terkandung dalam pala dan cengkeh adalah sebagai interpretasi antar hubungan di antara bahasa, kebudayaan, dan kognisi dengan teori Antropologi Kognitif yang di analisa secara struktur visual di budaya Masyarakat Ternate (Maluku Utara). Dalam Perspektif Antropologi Kognitif masyarakat Maluku Utara (Ternate) terdapat kajian Interpretasi terhadap Pala dan Cengkeh, yang berangkat dari latarbelakang mengenai masyarakat Maluku Utara (Ternate), serta falsafah yang terkait dengan ekologi masyarakat Ternate (Maluku Utara). Dalam pengkajian ini terdapat beberapa komponen yang dikaji diantaranya; masa perawatan Pala dan Cengkeh, masa sebelum panen pala, masa panen pala dan cengkeh, masa penjemuran dan penjualan pala dan cengkeh, hal ini merupakan interpretasi pada pala dan cengkeh kedalam filosofi Jujaro dan Ngungare Ternate (Maluku Utara). Tujuan dari Jurnal ini adalah bagaimana menyampaikan makna Pala dan Cengkeh dalam filosofi masyarakat Maluku Utara (Ternate) yang dipahami secara turun-temurun dan menjadi tradisi lisan yang dalam penyampaiannya berupa makna azali. Tulisan ini lebih terfokus pada analisis visual konsep pala dan cengkeh dengan mengacu pada teori Interpretasi dengan pendekatan Antropologi Kognitif dari masyarakat penggunanya. Sebagai hasilnya dalam Jurnal ini dibahas tentang analisa visual yang lebih terfokus pada makna filosofis dalam konsep Pala dan Cengkeh yang terkait dengan makna Jujaro dan Ngungare, sehingga sinergi dengan ekologi masyarakat lebih melihat pala dan cengkeh sebagai komuditi masyarakat, serta kontribusinya sebagai model kajian secara Teori Interpretasi dan Antropologi Kognitif dalam suatu tatanan masyarakat.
\end{abstract}

Kata Kunci-Pala dan Cengkeh, Ternate (Maluku Utara), Teori Interpretasi dan Antropologi Kognitif.

\footnotetext{
Abstract

Philosophical meaning contained in nutmeg and clove is an interpretation of interrelationships between language, culture and cognition with the theory of Cognitive Anthropology which is analyzed by visual structure in the culture of Ternate's People (North Maluku). In Cognitive Anthropology Perspective of North Maluku people (Ternate), there are studies of Interpretation of Nutmeg and Clove which departs from the backgrounds of the people of North Maluku (Ternate), as well as the philosophy associated with the ecological community of Ternate (North Maluku). In this study there are some components examined including: Nutmeg and Clove treatment period, the period before harvesting the Nutmag, nutmeg and clove harvest time, the drying and sale time, this is an interpretation of the nutmeg and cloves into Jujaro and Ngungare philosophy of Ternate (North Maluku). The purpose of this journal is to convey the meaning of Nutmeg and Clove in philosophy of North Maluku people (Ternate) which is understood by generations and becomes verbal tradition in its
} 
delivery in the form of immortal truth meaning. This paper is more focused on visual analysis of nutmeg and clove concept with reference to the interpretation theory of Cognitive Anthropology approach from the native society. As a result, this Journal discusses the visual analysis focused on the philosophical meaning in the concept of Nutmeg and Clove associated with the Jujaro and Ngungare meaning, so that it is synergy with the ecological community which is viewed nutmeg and cloves as society commodity, and its contribution as a model for studies in theory of Interpretation and Cognitive Anthropology in a social order.

Keywords - Nutmeg and Clove, Ternate (North Maluku), Theory of Interpretation.

\section{INTRODUCTION}

North Maluku is one of the new provinces in eastern Indonesia, which is the expansion of Maluku province. Although as a new province, North Maluku area has already been known by the world since the 14th century. North Maluku since centuries ago was producing spices especially nutmeg and cloves. Because of the result of these popular spices, North Maluku in the 14th century became one of the world's trade area. (Ternate 2004:2)

Nutmeg and clove, the main spice North Maluku community, is not merely a result of the Earth but in everyday society at North Maluku, nutmeg and cloves also has become an important part in the process of community life in the North Maluku especially areas of Ternate. Both in the structure of the Sultanate of Ternate, as well as local governance. (Ternate 2004:1) Ternate is one of the areas that applies the nutmeg and cloves into the arms of his territory and becomes patterns of life and the structure of society culture. It is reflected in the philosophical poems contained in its oral literature. Oral literature which is known in the community of Ternate such as Dolabololo, Tifa and Proposition Proposition Moro.

\section{Example: The Transcript \\ Evidence Moro \\ Ino fo ma kati nyinga \\ Doka gosora se buwalawa \\ Om doro yo ma mote \\ Fo ma gororu fo ma dudara}

It can be enterpreted as follow:

Let's tolerate
Like nutmeg with Mace

Mature trees and along

Based on love and affection.

North Maluku community especially of Ternate, in managing the nutmeg and cloves has certain processes in the handling. Both in the process of caring for, harvesting up to sell nutmeg and cloves they always heed the rule or Ordinance they have already received orally.

\section{RESEARCH METHODS}

In this study, the use of theory into something that is most mainstream. Where the use of Ethnographic theory is used as a theory to examine the structure of the community particularly in North Maluku Ternate and theory of interpretation to provide interpretation and analysis studies.

\subsection{Theory of Cognitive Cognitive}

Anthropology is a subfield of cultural anthropology that examines about interconnections among language, culture, and cognition (Sham 2007:49). In understanding the science of Cognitive Anthropology, the researcher tries to connect the structure of language in this oral literature of Ternate (postulate Moro), understanding the cultural community of Ternate about nutmeg and cloves, as well as the efforts of researcher in identifying something through the experience itself (cognition) through the process, introduction, and environmental interpretation of community as well as the results of Ternate, a knowledge acquisition of researcher about the culture in Ternate. 
Cognitive anthropology has close ties with the view that the culture contains thoughts, mood, feelings, beliefs, and values that are called prespective Phenomenology, cultural analysis and also looked at that analyzes the culture more see the content thoughts and feelings than the behavior (Sham 2007:50).

\subsection{Theory of Interpretation}

Interpretation itself can refer to a process of ongoing or interpretation of results. An interpretation can be a part of a presentation or portrayal of the modified information to comply with a set of specific symbols. The purpose of the interpretation usually is to improve understanding, gives an overview of the virtual state. Virtual state is a manifestation of what happens in writing, i.e. events that are taken from a selection of meaning, in the talks, from something that appears and begins (Ricoeur 2012:62).

The concept of Meta-lingguistic model is; the first describes the discourse directly not as a residue of the second language, it describes a structure of discourse and not only irrational events, and third, he subordinates the functions of the mark under the role of the communication connection. (Jakobson in Ricoeur 2012:42). While langue is a sign or rules based on the significance of any talks that result in parole as a special message (Ricoeur 2012:21) in which the understanding of this could take us to position of ourselves as researchers; with the Foundation of the research object of study.

\subsection{RESULTS and DISCUSSION}

Bualawa and Cengke or nutmeg and cloves is a fruit which is believed to be the community of Ternate as fruit from the sky/heaven, where in the public life of Ternate can be symbolized by the element Jujaro (female) and Ngungare (female). This philosophy which was later dianalisakan in the ethnographic society structure of Ternate, starting from the beginning of maintenance until the sale of nutmeg and cloves.

\subsection{Nutmeg}

In the introduction to the work of the task end Marsya Sustainably, explains that the fruit of the Nutmeg (Myristica fragrans) is a plant in the form of a tree that comes from the Maluku Islands. Due to its high value as a spice, nutmeg fruit and seeds have become an important trade commodity since Roman times. The term is also used for nutmeg seeds being traded.

The plant houses two (dioecious) so that it is known male and female trees. The leaves are elliptic-shaped trim. The fruit is oval shaped like lemons, yellow, fleshy and flavorful distinctive because it contains essential oils on the flesh of the fruit. When it is ripe, the skin and flesh of the fruit open and seeds will be seen draped in red Mace. One fruit produce one seed is brown.

Nutmeg fruit seed is harvested, the seeds (arillus), applaud, and the flesh of the fruit. In the trade, aril called Mace, nutmeg or mace called in the United Kingdom, in terms of the pharmacy called myristicae or arillus macis). The flesh of the fruit is called nutmeg myristicae fructus cortex. The first harvest is performed 7 to 9 years after the tree is planted and achieve maximum production capabilities after 25 years. The growth can reach $20 \mathrm{~m}$ and age can reach hundreds of years.

Before it is marketed, seed drying to dry after being separated from her Mace. Drying takes six to eight weeks. The inside of the seed will shrink in this process and will be heard when the seeds are shaked. Shell beans will burst and the inside of the seed sold as nutmeg.

Nutmeg seeds contain essential oil 7-14\%. Nutmeg powder is used as a flavoring for breads or cakes, puddings, sauces, vegetables, and refreshing drinks (such as eggnog). The oil is also used as a mixture 
of perfume or Soap. (Lestari Marsya 2016:47)

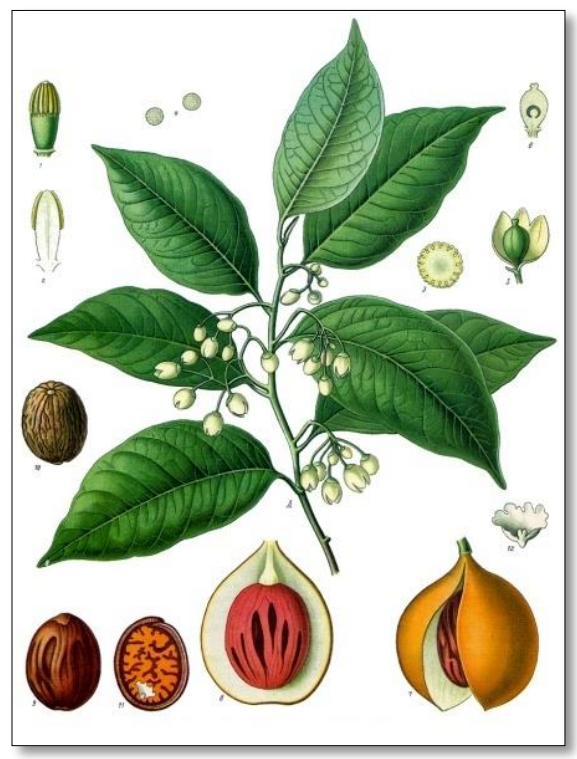

Figure 1: Nutmeg

\begin{tabular}{||c|c||}
\hline \multicolumn{2}{|c|}{ Nutmeg/Bualawa } \\
\hline \hline \multicolumn{2}{|c|}{ scientific classification } \\
\hline \hline The Goverment: & $\underline{\text { Plantae }}$ \\
\hline \hline Divided: & $\underline{\text { Magnoliophyta }}$ \\
\hline \hline Class: & $\underline{\text { Magnoliopsida }}$ \\
\hline \hline Ordo: & $\underline{\text { Magnoliales }}$ \\
\hline \hline Family: & $\underline{\text { Myristicaceae }}$ \\
\hline \hline Genus: & Myristica \\
\hline \hline Spesies: & M. fragrans \\
\hline \hline Binomial Name \\
\hline Myristica fragrans \\
\hline \hline
\end{tabular}

Table 1: Nutmeg

\subsection{Clove}

Similarly, in the introduction to the work of the task end Marsya Sustainably, explains that the fruit of Cloves (Syzygium aromaticum, SYN. Eugenia aromaticum) United Kingdom called cloves, sprigs of scented dried flower is from the family tree of the Myrtaceae. Clove is native to Indonesia, is widely used as a spice in spicy cuisine of European countries, and as the main ingredient in typical cigarettes Indonesia. The cloves are grown mainly in Indonesia (Banda Islands) and Madagascar; Nokia budidayakan in Zanzibar, India, Sri Lanka \&.

Indonesia which is the country's largest producer and user of cloves, which is about $80 \%$ (FAO, 2005), which was followed by Madagascar and Tanzania. Cloves are the main ingredients of typical cigarettes Indonesia.

Generally clove first bear after 4-7 years. Cloves will be harvested after reaching a length of 1,5-2 cm. In Indonesia, cloves are very suitable for planted well in lowland areas near the coast or in the mountains at an altitude of $900 \mathrm{~m}$ above sea level. (Lestari Marsya 2016:45) $^{1}$

1 Pengantar Karya Tugas Akhir. "Karakter Animasi 2D Bertema Rempah Sebagai Pengenalan Cengkeh \& Pala pada Anak Usia 711 Tahun". Desain Komunikasi Visual, Fakultas Industri Kreatif, Universitas Telkom. 


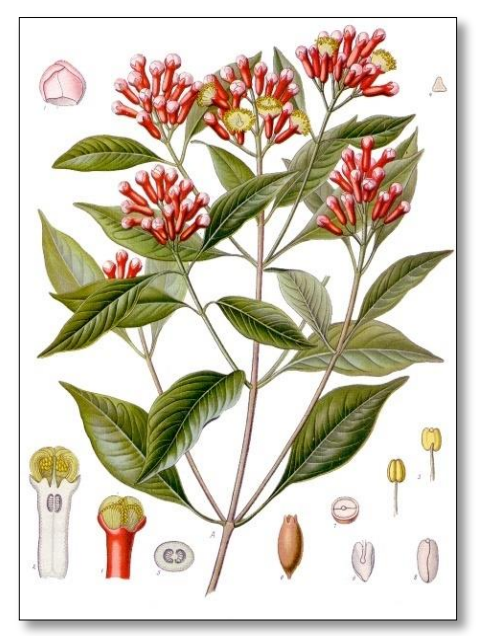

Figure 2: Clove Tree

\begin{tabular}{|l|l||}
\hline \multicolumn{2}{|c|}{ scientific classification } \\
\hline \hline The Goverment: & Plantae \\
\hline Divided: & Angiospermae \\
\hline \hline (Not Included): & Eudikotils \\
\hline (Not Included): & Rosids \\
\hline \hline Ordo: & Myrtales \\
\hline \hline Family: & Myrtaceae \\
\hline \hline Genus: & Syzygium \\
\hline Spesies: $\quad$ aromaticum \\
\hline \hline \multicolumn{2}{|c|}{ Nama binomial } \\
\hline \hline \multicolumn{2}{|c|}{ Syzygium aromaticum } \\
\hline
\end{tabular}

Tabel 2: Clove

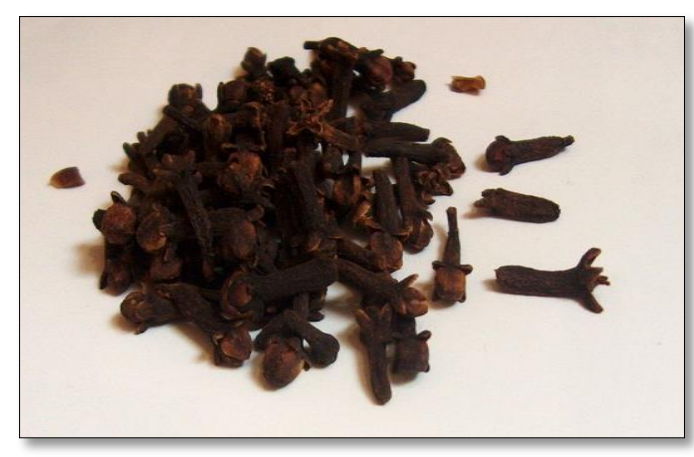

Figure 3: Clove

\subsection{Structure of the Visual Analysis}

The analysis in the visual Concept is a form of transformation of the visual structure of the forms contained on the clove and nutmeg. Where in the structure of visual Clove and nutmeg before the elaboration of the concept of clove and nutmeg fruit anatomy become the cornerstone of early visual. This form later in the transformasikan becomes a draft or the visual meaning that is more philosophical, based on understanding of Cognitive Anthropology interpreted into the visual meaning theoretically.

\subsection{Structure of the Nutmeg Philosophy}

In reading order, there are Nutmeg Anatomy describing the structure of the nutmeg fruit, especially in the visual structure. It is clearly visible in visual nutmegs which become the structure of its anatomy as a whole of nutmeg seeds to fruit stalk itself. 


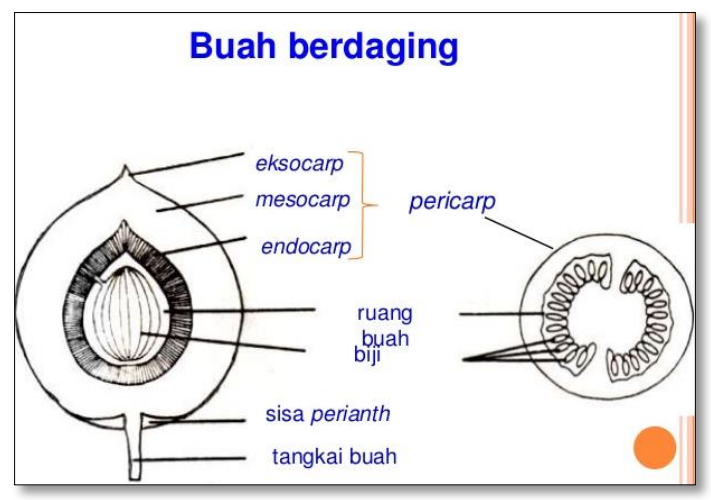

Figure 4: Shovel Structure

In the anatomy of nutmegs, there are layers that make up the visual structure, where in the structure of visual nutmegs can be interpreted with the description of an embodiment of the Yoni (Vagina). It is unexplained from Cognitive anthropology in community ecology from North Maluku especially Ternate in treating the nutmeg fruit.

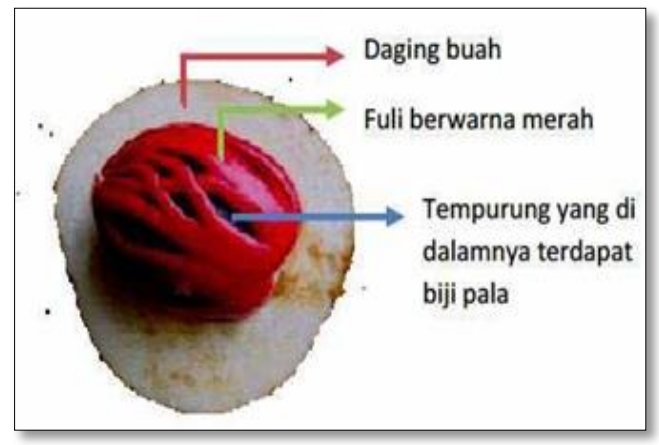

Figure 5: Shovel Anatomy

Community ecology in North Maluku, in treating the fruit of the nutmeg has a philosophical meaning. It can be seen how communities of North Maluku especially Ternate in harvesting the fruit of the nutmeg as major commodity trading for them. In gardening nutmegs, North Maluku community do the procession gradually, starting from: 1) the process of caring for plants, 2) entering a period of harvest, 3) the process of harvesting, drying out and 4) as well as the process of selling nutmegs.

1) in the process of taking care of nutmeg trees, North Maluku community is always done by the women who clean the nutmeg trees growing place land of grass and weeds that are disturbing, while men more on guarding the branches and twigs nutmeg trees which direction they complicate the process of harvesting later. This can be interpreted philosophically into the structure of meaning, the meaning of which illustrates how the North Maluku community in maintaining and raising woman. The house wife always taught the meanings of social manners and that is in the culture of North Maluku. While the House of Dads on duty is to maintain the child brides from steps that would defame the good name of the family and the child's name itself.

2) Entering a period of harvest, North Maluku community always prepares everything that is later used in the time of harvest. Women prepare soloi $^{2}$, susiru3 (Ahmad 2011:195). While the men prepare the stairs and dubo-dubo (a kind of milestone gala/to pick fruit) to pluck the nutmeg (Ahmad 2011:40). In addition, North Maluku community also always does prayers (on tahlilan), manae nutmeg (which involves the owner and workers) as well as the Almighty God (as the owner of sustenance) this is a three-power (triangle powers), related one another. This is meant as a family readiness in preparing young woman before entering adulthood (Ahil behind), with a strong religious knowledge would later when the young woman became a mother in the future.

3) Harvesting process into a procession that is very interesting, because the procession is regarded as the main procession in the whole rituals. Where a procession of this harvest is better done by men, where the quotation in the nutmeg fruit is just the nutmegs that have already broke/split and look seed nutmeg and Mace.

1 Soloi, Wadah untuk menampung hasil kebun berbentuk kerucut dari bahan dasar anyaman bambu

${ }^{1}$ Susiru, Wadah untuk menampi berbentuk bulat berbahan dasar anyaman bambu 
Where as womankind stint to gather nutmegs into soloi.The procession of the harvest of nutmeg means a biological structure that occurs in young girls, in which a woman is considered an adult at the time she started menstruation. Nutmegs are split and look fuli ${ }^{4}$ red is the depiction of women who have irregular periods/menstrual.

4). The process of selling, in this process of North Maluku community always does it together. Where the nutmeg crop separated seeds and fruit from the meat and then Mace is dried until it is dried. As for the flesh of the fruit sold, nutmeg made confectionary (Nutmeg), nutmeg seeds sold as spice, and Mace as the basic ingredients of cosmetics or drugs. Usually a Mace becomes the most expensive part of the whole nutmegs. It also happens in the tradition of North Maluku community, women should be able to take care of the family and the children. Mace which is a depiction of a biological structure in adult women is an expensive value (Virginity), because it is a prestige from the family. Besides communities North Maluku in culture puts women in a very high position, cherished and guarded her honour, because according to the culture of the North Maluku community in myth 7 Princess, all the women are descendants of the Lady from the sky.

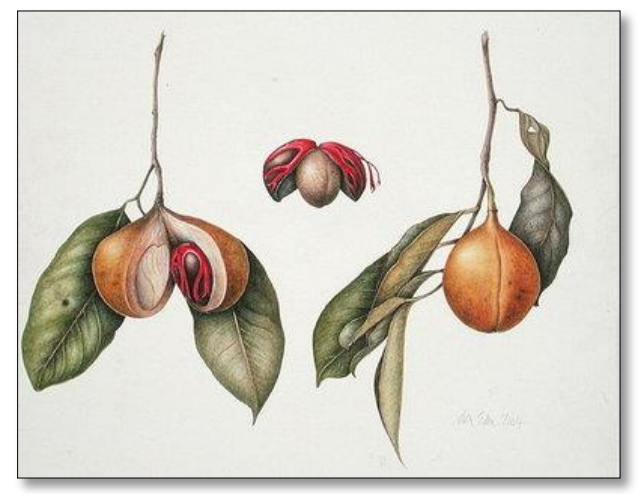

Figure 6: Fuli in Shovel

\subsection{Structure of the philosophy of Clove}

In the reading of the order there are Clove Anatomy describes the structure of the Clove fruit, especially in the visual structure. Clearly visible on the Cloves into the fruit of the visual structure of its anatomy is a whole of fruit stalk up to the Crown of the Clove itself.

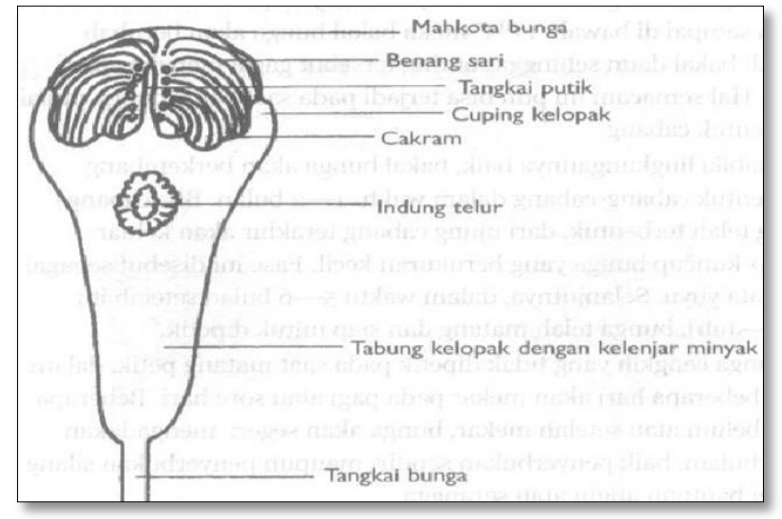

Figure 7: Clove Structure

Clove fruit in anatomy, there are layers that make up the visual structure, which in the visual structure of fruit and cloves can be interpreted with the description of an embodiment of the phallus (Testicles). This unexplained from Cognitive anthropology in community ecology from North Maluku especially Ternate in treating fruit and cloves.

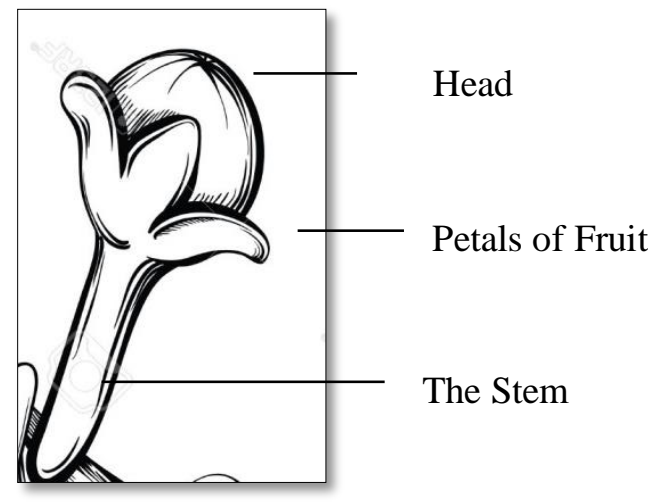

Figure 8: Clove Anatomy 
Community ecology of North Maluku, in maintaining plant cloves contain philosophical. This can be seen from how society North Maluku/Ternate in maintaining plant clove which is one of their main spice. In maintaining plant cloves, North Maluku community does the procession gradually, starting from: 1) the process of caring for plants, 2) harvest, and 3 ) drying process fruit and cloves.

The process of caring for North Maluku community clove or Ternate, there really isn't much different than planting trees. It is always done by the women who clean up the land around the growth of trees and grass thatch cloves of which interfere with, while men are more on guarding the branches and twigs that clove directions complicate them on the process of harvesting later. This describes how the North Maluku community keep their lineage, which has been existed in boys (Ngungare). In view of the public or Ternate, North Maluku boys are the dignity of lineage bearers (Marga) so that in bringing up her son's North Maluku community or Ternate constantly infuse nature which is based on ' my and saying. Have a sense of responsibility and willing to work hard in his life. The rules in the mom who cares more then maintained its continuity by the father.

Clove harvest also is a procession that is sacred and very religious. North Maluku community or Ternate always begin with a ritual pray at tahlilan or activities which are often called manae clove (which involves the owner and workers) and Almighty God (as the owner of sustenance) is the three powers (the triangle powers), intertwined with each other. A procession of manae cloves will begin with the stages of prayer (tahlilan). The power factor of the three, is understood that the source of the beginning of any provision shall be a factor that cannot be ignored in the search for sustenance and to retain the gift of sustenance, then humans must pray and work. Clove harvest procession is only done when the clove fruit shell has already started to blush and split so it looks cengkehnya interest, because in the understanding the people of Ternate, North Maluku or clove fruit that is ready for harvest is a depiction of a Ngungare already at circumcision/hitan or deemed sufficiently mature in bearing responsibility. It is based on understanding which becomes the majority belief of the people.

The process of drying fruit and cloves is basically not much different from the fruit of the nutmeg, but in North Maluku community habits or Ternate, cloves drying process is more than a natural process because the use of the Sun as main heat element. As apart of good drying results, North Maluku community or Ternate contended what became a boon over the natural environment is crucial to put to their best and as necessary. Because of the community view that has positive attitude in maintaining and distanced itself from the destruction of the crop against natural clove and its environment is a noble nature.

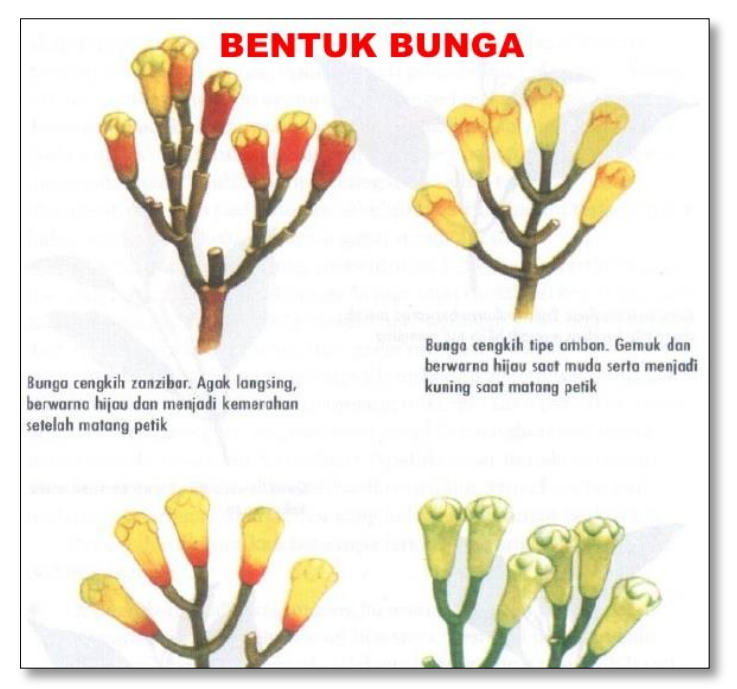

Figure 8: Clove Anatomy

North Maluku community or Ternate in clove tree maintenance always see their environment, so that they could be fair in sharing the results keep the natural environment as well as the sustainability of their dwellings. It is believed that consciousness is in line with what is contained in the Qur'an Surah Ar-Rum verse 41, which signals of damage on Earth are done by man. Therefore society of North Maluku or Ternate always perform a 
procession to pray (tahlilan) in starting everything related to culture harvest cloves and nutmeg, this is referred to as consciousness in minimize or avoid the damage to the good for the owners, workers as well as tree clove and results.

The elaboration of the concept between the visual analysis of structure contained in the nutmeg and cloves harvest procession in North Maluku community or Ternate, clearly seen that the meaning of "Jujaro (female) and Ngungare (female)" in culture item of the community North Maluku, closely related to the philosophical meaning informing customs and rules of behaviour in North Maluku community itself. The visual meaning or the interpretation of cultures that exist in the cultural context or Ternate, North Maluku is the acclamation of the people, and manifesting in oral forms, visuals, text, and rules which exist in society.

\section{CONCLUSION}

The elaboration of cognitive Anthropology is the manifestation in the forms of oral, visual, writing, and rules existing in the society in the form of cultural phenomena, religion, society, and politics in the society Archipelago. The meanings revealed in philosophy with scientific interpretation in structure with a scientific approach, thought to be able to visualize the meaning of azali contained in community ecology in North Maluku or Ternate. The variety of comprehension is also meant by the people of Ternate (North Maluku), where their daily lives in the nutmeg and cloves is something mediocre, but unwittingly have been formed in accordance with the structure they've believed as a philosophy of life. By using the theory of interpretation of Ricoeur Paui runway approach to Cognitive Anthropology, the meaning of azali on nutmeg and cloves are related to the culture and philosophy that there is in the community of Ternate (North Maluku) breakfast buffet in clear. In an attempt to interpret the meaning of the philosophy of nutmeg and cloves on the understanding of the people of Ternate (North Maluku), do approach with studies of Cognitive anthropology and interpretation related to behavior and habit of Ternate (North Maluku) community in interacting with nature.

That is an important element in the structure of the philosophy of nutmeg and cloves with interpretations in Cognitive anthropology society meaning Ternate (North Maluku) is, the integration of the meaning of visual interrelationships among language, culture, and cognition the mythology of the nutmeg and cloves in the community of Ternate (North Maluku). Approach to analysis of interpretation developed by Paul Ricour with an understanding of cognitive Anthropology Nur Sham analysis: 2007. In this study the position of the philosophical meaning of nutmeg and cloves in the public life of Ternate (North Maluku) has an important understanding of the related structure of Jujaro life and Ngungare of the people. The structure of the same meaning, is the integration of the relationship between language, traditions and natural environment, even a unified and interdependence between one another. In this study of breakfast buffet that the meaning of the philosophy of nutmeg and cloves which is the integration between the structure of Jujaro and Ngungare in the life of the community of Ternate (North Maluku), this is not an irrelevant, but it is the meaning that azali understood in the community ecology of srtucture in Ternate (North Maluku). It was this meaning to be understood in the life of contemporary society of Ternate (North Maluku) and it can become a scientific understanding to know back structure in the community of ecological significance. It is an important element in the structure the philosophy of nutmeg and cloves with interpretation in the meaning of Cognitive anthropology society Ternate (North Maluku) is, the integration of the meaning of visual interrelationships among language, culture, and cognition mythology found in the nutmeg and cloves in the community of Ternate (North Maluku). Approach to analysis of 
interpretation developed by Paul Ricour with an understanding of cognitive Anthropology Nur Sham analysis: 2007. In this study the position of the philosophical meaning of nutmeg and cloves in the public life of Ternate (North Maluku) has an important understanding of the related structure of Jujaro life and Ngungare of the people. The structure of the same meaning, is the integration of the relationship between language, traditions and natural environment, even a unified and interdependence between one another. In this study of breakfast buffet that the meaning of the philosophy of nutmeg and cloves which is the integration between the structure of Jujaro and Ngungare in the life of the community of Ternate (North Maluku), this is not an irrelevant, but is the meaning that azali understood in the community ecology of srtuktur Ternate (North Maluku). It was this meaning that was able to be understood in the life of contemporary society Ternate (North Maluku) and can become a scientific understanding to know back structure in the community of ecological significance.

\section{ADVICE}

To review the research related to the anthropological community, it is advisable to know the object of his research thoroughly. This is because what we review the important thing that is directly related to the community users.

To further complement the studies or research, if more dititip focus on the philosophical meanings that exist in the community of North Maluku (Ternate) in interpret nature.

\section{THANKYOU}

The authors thank the deepest gratitude to all those who have been giving moral and financial support towards this research.

\section{BIBLIOGRAPHY}

[1] Pemerintah Kota Ternate, 2004, Sejarah Kota, Ternate, potensi dan peluang investasi, Pemerintah Kota Ternate INFOKOM, Hal $1 \& 2$.

[2] Nur Syam, 2007. Madzhab-madzhab Antropologi, LKiS, Yogyakarta

[3] Paul Ricoer, 2012, Teori Interpretasi Memahami Teks, Penafsiran, dan Metodologinya, IRCiSoD, Jogjakarta

[4] Marsya Lestari, 2016, Karakter Animasi 2D Bertema Rempah Sebagai Pengenalan Cengkeh \& Pala pada Anak Usia 7-11 Tahun, Pengantar Karya Tugas Akhir, Desain Komunikasi Visual-Fakultas Industri Kreatif, Universitas Telkom, Bandung.

[5] Mahdi Ahmad, 2011, Kamus TernateIndonesia-Inggris, UPI PRESS, Bandung. 